\section{Waterfowl Production on Stock-Watering Ponds in the Northern Plains}

\section{JOHN T. LOKEMOEN}

Highlight: In a 5-year study of stock-watering ponds in western North Dakota, pond size was found to be the major factor influencing duck use. As pond size increased, total pair and brood use per pond increased. Pairs used ponds as small as 0.1 acre in size, but broods were seldom seen on ponds of less than 1.0 surface acre. Dam-type ponds larger than 1.0 surface acre comprised only $29 \%$ of all man-made ponds on the study area but received $65 \%$ of the pair use and $87 \%$ of the brood use. Utilization of fenced ponds by pairs and broods was not significantly different from utilization of unfenced ponds. Grazing rates of 2 to 3 acres per AUM and lower rates permitted the development of grassy shoreline cover preferred by pairs and brushy and emergent shorelines preferred by broods. Duck pairs were significantly more numerous on older ponds and ponds with grassy shorelines but less numerous on ponds that had heavy deposits of sediment or were isolated from other wetlands. Broods were significantly more numerous on ponds with brushy shorelines and emergent vegetation than on those without. Broods were less numerous on turbid and newly constructed ponds. The most suitable stock-watering units for maximum waterfowl production were damtype ponds of 1.5 surface acres, or larger, built in gentle to rolling terrain away from major sources of siltation.

Land-use agencies involved with building ponds to water livestock are becoming more interested in including features that will enhance the value of these man-made wetlands for wildlife. Planning for these programs has prompted questions including: (1) what design criteria result in the most attractive waterfowl pond, and (2) how should ponds and the adjacent uplands be managed? To answer these questions, a study was initiated in 1966 to ascertain the relationships between breeding waterfowl and the design, location, and management of marl-made wetlands.

\section{Study Area}

From 1967 through 1970 the study was generally confined to the 9- by 4-mile Tracy Mountain Study Area located in western North Dakota, 9 miles southwest of Belfield. Data gathered in 1966 from other ponds located in the vicinity of Bel-

The author is wildlife biologist, Northern Prairie Witdlife Research Center, Bureau Sport Fisheries \& Wildlife, Jamestown, North Dakota. The author would like to thank Harvey Miller and Paul Springer for their suggestions during the study and their constructive reviews of the manuscript, Douglas Johnson for statistical treatment of the data, and personnel of the U. S. Forest Service for assistance in various aspects of the study.

Manuscript received September 29, 1972. field and west of Pierre, S. Dak., were also used.

The Tracy Mountain Study area lies in a region with cold winters and warm summers. The growing season averages 120 days. The average annual temperature at Dickinson, 25 miles northeast of the study area, is $40.7^{\circ} \mathrm{F}$, and the average annual precipitation 15.4 inches (U. S. Dep. of Commerce, 1970). Approximately $75 \%$ of the study area was in the Little Missouri River watershed, made up of Bainville-Morton Association soils on a hilly and extensively eroded badlands topography. The remainder was in the Heart River watershed, consisting of Rhoades-Morton Association soils on a rolling topography,

Eighty-eight percent of the study area was rangeland on which the dominant vegetation was blue grama (Bouteloua gracilis), western wheatgrass (Agropyron smithii), and threadleaf sedge (Carex filifolia). The remainder was cropland planted primarily to feed grains and hay, mainly smooth brome (Bromus inermis) and alfalfa (Medicago sativa). About $60 \%$ of the land is managed by the U. S. Forest Service as part of the Little Missouri River National Grasslands.

For this report, stock-watering ponds were classified into three types similar to those defined by Bue et al. (1964): Stock ponds, formed by building dams across waterways; dugouts, consisting of steepsided excavations filled by runoff water or ground water; and diked-dugouts, constructed like dugouts except with the spoil placed in a downstream embankment so that a shallow area around the excavation may be flooded. Natural wetlands were mainly small, temporary creek pools.

\section{Methods}

The pond turbidity rating was the depth at which a submerged white disc 3 inches in diameter disappeared from view. Pond size and distance between water areas were measured from aerial photographs. Ponds were considered silted when clay sediment deposits covered the majority of the impoundment bottom. At each pond the percent of surface water with emergent vegetation was estimated visually; and the amount of shoreline that was bare, grassy (grasses and sedges 1 to 24 inches in height), or brushy was measured. Changes in water levels in relation to the spillway elevation were measured during each pond visit. The amount of pond area that was 0.0-1.0, $1.1-2.0$, and $2.1-3.0 \mathrm{ft}$ deep was determined by computing the average width of the contour and multiplying by the length. The height and density of shoreline vegetation $6 \mathrm{ft}$ from the water was measured with a cover board similar to that used by Jones (1968).

Each year between late April and early
June, two to four counts of breeding pairs of waterfowl were made on all ponds on the study area, including creek pools. The highest pair count for each species for the entire study area was chosen to represent the breeding population. Mallard and pintail breeding pairs were chosen from the April and early May counts, and the breeding pairs of the later nesting species were taken from the mid and late May counts.

Two complete brood counts were made each year, onc in mid-July and one in early August. Production was the total number of broods observed on the two counts less possible duplicate broods on the second count. The productivity rate was obtained by dividing the number of broods by the number of breeding pairs.

For analyzing duck-habitat relationships, "pair use" of a pond was the average of two pair counts; mallards and pintails were totaled from the first two counts and the other species from two of the later counts. The average number of broods seen on the pond during the two brood counts was considered "brood use."

Analyses of duck use by species with pond habitat measurements were made on an IBM System 360/50 using a correlation and multiple linear regression program. 


\section{Results and Discussion}

Of the 68 man-made ponds on Tracy Mountain Study Area, 50 were stock ponds, 6 were dugouts, and 12 were diked-dugouts. The ponds ranged in size from 0.04 to 5.9 surface acres and averaged 1.0 acre. Stock ponds averaged 1.4 surface acres, dugouts 0.2 acre, and dikeddugouts 0.3 acre. Creek pools comprised an average of $6 \%$ of the water acreage on the study area during the 4 years.

\section{Duck Breeding Population and Production}

The duck breeding population on the study area averaged 3.3 pairs per square mile, 1.8 pairs per acre of stock-watering ponds, and 1.9 pairs per acre of all water. This compares with 7.0 pairs per square mile and 2.3 pairs per acre of stockwatering pond in western South Dakota (Bue et al., 1952). The mallard was the most numerous of the seven species of breeding ducks, comprising $50 \%$ of the population (Table 1). Other important species included the American widgeon, pintail, and blue-winged teal. Twelve percent of the breeding pairs were found on natural wetlands; the rest were on manmade ponds.

Broods averaged 1.4 per square mile, 0.79 per acre of stock-watering pond, and 0.83 per acre of all water (Fig. 2). In 0.83 per acre of all water (Fig. 1). In comparison, Bue et al. (1952) found broods per acre of man-made pond on their study area. Productivity on the Tracy Mountain Study Area averaged $44 \%$ during the 4 years. This is in the higher range of productivity reported in recent prairie studies (Keith, 1961) but below the $65 \%$ productivity found by Bue et al. (1952). Ten percent of the

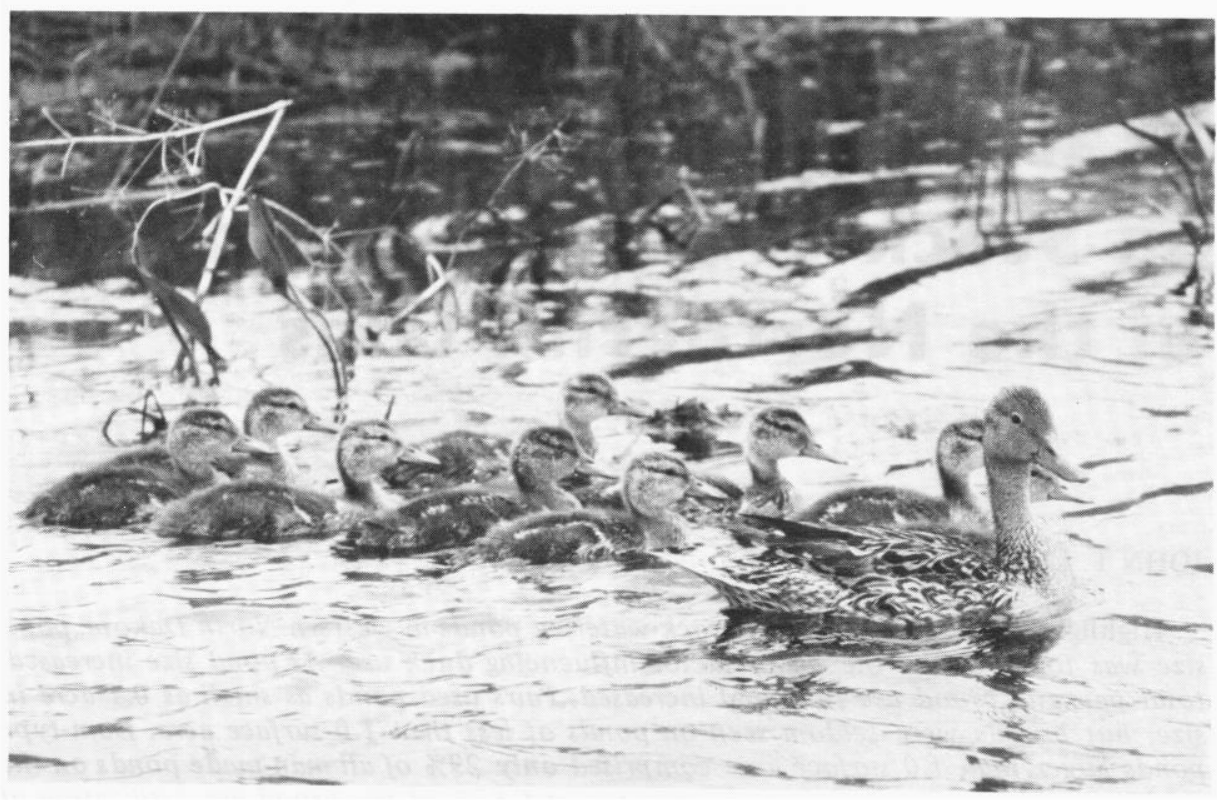

Fig. 1. Pintail brood of nine on a western North Dakota stock pond.

broods were observed on creek pools and $90 \%$ on man-made ponds.

\section{Duck Use by Pond Size and Type}

Of the habitat features considered, pond size was most highly correlated $(r=$ $0.71)$ with duck use. Pairs used ponds as small as 0.1 acre; however, the average number of pairs was higher on the larger ponds (Table 2). Sixty-five percent of the pair use was on $29 \%$ of the ponds that were larger than one surface acre. Smith (1953) and Berg (1956) reported similar findings in Montana. The increase in duck use was less than proportional to the increase in pond size; the smaller ponds had the highest average number of pairs per surface acre. Evans and Black (1956) reported that duck use per acre of natural

Table 1. Duck breeding population and brood production on the Tracy Mountain Study Area, 1967-70.

\begin{tabular}{|c|c|c|c|c|c|}
\hline \multirow[b]{2}{*}{ Species of duck } & \multicolumn{2}{|c|}{ Breeding pairs } & \multicolumn{2}{|c|}{ Broods } & \multirow{2}{*}{$\begin{array}{l}\text { Productivity } \\
\text { rate }(\%)\end{array}$} \\
\hline & Total & Percent & Total & Percent & \\
\hline $\begin{array}{l}\text { Mallard } \\
\quad \text { (Anas platyrhynchos) }\end{array}$ & 234 & 50 & 94 & 46 & 40 \\
\hline $\begin{array}{l}\text { Gadwall } \\
\quad \text { (Anas strepera) }\end{array}$ & 18 & 4 & 10 & 5 & 56 \\
\hline $\begin{array}{l}\text { Pintail } \\
\qquad \text { (Anas acuta) }\end{array}$ & 59 & 13 & 13 & 6 & 22 \\
\hline $\begin{array}{l}\text { Green-winged teal } \\
\quad(\text { Anas carolinensis })\end{array}$ & 20 & 4 & 11 & 5 & 55 \\
\hline $\begin{array}{l}\text { Blue-winged teal } \\
\quad \text { (Anas discors) }\end{array}$ & 55 & 12 & 37 & 18 & 67 \\
\hline $\begin{array}{l}\text { American widgeon } \\
\quad(\text { Mareca americana })\end{array}$ & 70 & 15 & 34 & 17 & 49 \\
\hline $\begin{array}{l}\text { Shoveler } \\
\quad \text { (Spatula clypeata) }\end{array}$ & 15 & 3 & 7 & 3 & 47 \\
\hline Total or average & 471 & 101 & 206 & 100 & 44 \\
\hline
\end{tabular}

wetlands varied inversely with size and that, although most of the pairs were on larger ponds, the smallest areas received the heaviest use per acre.

On a surface-acre basis, pair use did not differ significantly $(P=0.05)$ among the three pond types. On a unit-pond basis, stock ponds, being larger, were by far the most important to breeding pairs. The excavated ponds were small, and the average pair use per dugout was only one-sixth that per stock pond. The average pair use per diked-dugout was onethird that per stock pond.

Brood use was also related strongly to pond area but somewhat differently from pair use (Table 3). As pond area increased, the number of broods per pond increased; but the highest number of broods per acre was found on intermediate-sized ponds 1.1-2.0 acres in size not on the smallest ponds, as was the case with pairs. Ponds under 0.25 acre received virtually no use by broods and those under 1 acre little use. Two other studies, one of man-made ponds (Berg, 1956), and one on natural wetlands (Evans and Black, 1956), also recorded few broods on ponds less than 0.5 acre. Only $29 \%$ of the man-made ponds on the study area were over 1.0 acre in size, yet they contained 87 percent of the brood use. Average brood use per dugout and diked-dugout was 2 to $3 \%$ of that per stock pond.

The average brood size for four pond size classes was calculated from observations in which the entire brood was sighted (Table 4). When Sheffe's multiple 
Table 2. Breeding pair use* related to pond size (acres) and type.

\begin{tabular}{|c|c|c|c|c|c|c|c|c|c|}
\hline \multirow[b]{2}{*}{ Pond size } & \multicolumn{3}{|c|}{ Stock pond } & \multicolumn{3}{|c|}{ Diked-dugout } & \multicolumn{3}{|c|}{ Dugout } \\
\hline & $\begin{array}{l}\text { Total no. } \\
\text { pond counts }\end{array}$ & $\begin{array}{l}\text { Pair use } \\
\text { per acre }\end{array}$ & $\begin{array}{l}\text { Pair use } \\
\text { per pond }\end{array}$ & $\begin{array}{l}\text { Total no. } \\
\text { pond counts }\end{array}$ & $\begin{array}{l}\text { Pair use } \\
\text { per acre }\end{array}$ & $\begin{array}{l}\text { Pair use } \\
\text { per pond }\end{array}$ & $\begin{array}{l}\text { Total no. } \\
\text { pond counts }\end{array}$ & $\begin{array}{l}\text { Pair use } \\
\text { per acre }\end{array}$ & $\begin{array}{l}\text { Pair use } \\
\text { per pond }\end{array}$ \\
\hline $0.04-0.24$ & 20 & 4.1 & .6 & 17 & 2.5 & 0.5 & 47 & 2.3 & 0.4 \\
\hline $0.25-0.54$ & 52 & 2.4 & 1.0 & 31 & 2.9 & 1.1 & 10 & 1.5 & 0.5 \\
\hline $0.55-1.0$ & 53 & 1.4 & 1.0 & 5 & $* *$ & $* *$ & 0 & - & - \\
\hline $1.1-2.0$ & 60 & 1.8 & 2.9 & 0 & - & - & 0 & - & - \\
\hline $2.1-5.0$ & 48 & 1.4 & 4.3 & 0 & - & - & 0 & - & - \\
\hline $5.1+$ & 15 & 0.9 & 7.1 & 0 & - & - & 0 & - & \\
\hline Total & 248 & & & 53 & & & 57 & & \\
\hline Average & & 1.9 & 2.4 & & 2.5 & 0.8 & & 2.2 & 0.4 \\
\hline
\end{tabular}

*Pair use of a pond was the average of two pair counts for each year.

**Too few pond counts to calculate use.

Table 3. Brood use* related to pond size (acres) and type.

\begin{tabular}{|c|c|c|c|c|c|c|c|c|c|}
\hline \multirow[b]{2}{*}{ Pond size } & \multicolumn{3}{|c|}{ Stock pond } & \multicolumn{3}{|c|}{ Diked-dugout } & \multicolumn{3}{|c|}{ Dugout } \\
\hline & $\begin{array}{c}\text { Total no. } \\
\text { pond counts }\end{array}$ & $\begin{array}{l}\text { Brood use } \\
\text { per acre }\end{array}$ & $\begin{array}{c}\text { Brood use } \\
\text { per pond }\end{array}$ & $\begin{array}{l}\text { Total no. } \\
\text { pond counts }\end{array}$ & $\begin{array}{l}\text { Brood use } \\
\text { per acre }\end{array}$ & $\begin{array}{l}\text { Brood use } \\
\text { per pond }\end{array}$ & $\begin{array}{c}\text { Total no. } \\
\text { pond counts }\end{array}$ & $\begin{array}{l}\text { Brood use } \\
\text { per acre }\end{array}$ & $\begin{array}{c}\text { Brood use } \\
\text { per pond }\end{array}$ \\
\hline $0.01-0.24$ & 26 & 0.00 & 0.00 & 20 & 0.00 & 0.00 & 53 & 0.09 & 0.02 \\
\hline $0.25-0.54$ & 44 & 0.13 & 0.06 & 25 & 0.12 & 0.04 & 7 & 0.00 & 0.00 \\
\hline $0.55-1.0$ & 56 & 0.37 & 0.27 & 5 & $* *$ & $* *$ & 0 & - & - \\
\hline $1.1-2.0$ & 54 & 0.68 & 1.02 & 0 & - & - & 0 & - & - \\
\hline $2.1-5.0$ & 46 & 0.56 & 1.78 & 0 & - & - & 0 & - & - \\
\hline $5.1+$ & 14 & 0.27 & 2.11 & 0 & - & - & 0 & - & - \\
\hline Total & 240 & & & 50 & & & 60 & & \\
\hline Average & & 0.38 & 0.77 & & 0.06 & 0.02 & & 0.08 & 0.02 \\
\hline
\end{tabular}

*Brood use of a pond was the average of two brood counts for each year.

$* *$ Too few pond counts to calculate use.

comparison test was applied, average brood size was significantly smaller on the 0.0 - to 1.0 -acre class $(P<0.05)$ and the 5.1 -acre and larger class $(P<0.10)$ than on the 2.1- to 5.0-acre class. Average brood size on ponds 2.1-5.0 acres in size was greater than on ponds 1.1-2.0 acres, but the difference is not significant $(P=$ $0.05)$. Thus, brood sizes and apparent survival of young were higher on the intermediate-size ponds, which also received the highest brood use per acre. Small ponds may contain insufficient surface area for brood security. In Canada, Stoudt (1971) found that broods forced to use dugouts about 0.1 acre in size survived less than 1 week. On the Tracy Mountain Area, ponds over 5.0 acres may contain smaller broods than intermediate-size ponds because they

Table 4. Average brood size for four sizes (acres) of ponds.

\begin{tabular}{lcc}
\hline \hline $\begin{array}{l}\text { Pond } \\
\text { size }\end{array}$ & $\begin{array}{c}\text { Number } \\
\text { broods }\end{array}$ & $\begin{array}{c}\text { Average } \\
\text { size }\end{array}$ \\
\hline $0.0-1.0$ & 22 & 4.7 \\
$1.1-2.0$ & 35 & 5.9 \\
$2.1-5.0$ & 47 & 7.0 \\
$5.1+$ & 15 & 5.1 \\
Total or average & 119 & 6.0 \\
\hline
\end{tabular}

generally form a harsher environment for broods by often being deep, open, and windswept.

\section{Duck Use of Fenced and Unfenced Shorelines}

Because of compacting by winter snows, the height and density of standing shoreline vegetation in spring along fenced ponds was not significantly greater $(P=0.05)$ than that along unfenced ponds (Table 5). Pair use per wetland acre did not differ significantly $(P=0.05)$ between the two shoreline types. However, by summer, the plants were higher on fenced ponds, and the plant density was apparently greater (Fig. 2). Brood use per wetland acre, however, was the same on both fenced ponds and unfenced ponds.

The shoreline comparisons were made on grasslands utilized by cattle from May 1 to November 30 at a moderate rate of about 1.5 to 3.0 acres per AUM. Waterfowl might respond positively to vegetation protected from livestock on ranges with heavier grazing pressure. However, the increase in waterfowl use would have to be considerable to justify the expense, because the avcrage cost to fence each pond on the study area was estimated at $\$ 500$.

\section{Duck Use of Watersheds}

Pair use in the rugged Little Missouri River watershed was compared to that in the rolling Heart River watershed. The average pond size was the same in each of the two watersheds; however, the Heart River watershed had 3.1 ponds per square mile, while the Little Missouri had only 1.5. Ponds in the Heart River watershed had significantly $(P<0.05)$ more stable water levels, less bare shore, more emergent vegetation, and more grassy shoreline than those in the Little Missouri River watershed.

Mallards were equally distributed on the two watersheds and were apparently little affected by habitat differences (Table 6). According to a contingency table analysis, pintails, blue-winged teal, American widgeon, and shovelers were significantly $(P<0.05)$ more common per wetland in the Heart River drainage. Gadwall were more numerous in the rolling terrain but not significantly so, while green-winged teal were more common in badland ponds. In all, pairs occupied Heart River ponds at twice the density of Little Missouri River ponds.

Although breeding pairs preferred the more marsh-like Heart River ponds, no direct correlation between the amount of pond shoal area and pair use was evident. 
Table 5. Comparison of vegetation measurements and waterfowl use on fenced and unfenced ponds, 1967-70.

\begin{tabular}{llcccc}
\hline Season & $\begin{array}{c}\text { Pond } \\
\text { treatment }\end{array}$ & $\begin{array}{c}\text { Number of } \\
\text { ponds surveyed }\end{array}$ & $\begin{array}{c}\text { Average plant } \\
\text { height (inches) }\end{array}$ & $\begin{array}{c}\text { Average plant } \\
\text { density }(\%)\end{array}$ & $\begin{array}{c}\text { Average } \\
\text { waterfowl use }\end{array}$ \\
\hline \multirow{2}{*}{ Spring } & Fenced & 21 & 3 & 11 & 3.0 pairs/acre \\
& Unfenced & 27 & 3 & 8 & 3.6 pairs/acre \\
\multirow{3}{*}{ Summer } & Fenced & 30 & $12^{* *}$ & 48 & 1.4 broods/acre \\
& Unfenced & 35 & $7^{* *}$ & 28 & 1.4 broods/acre \\
\hline
\end{tabular}

**Significant difference at the 0.05 probability level.

Table 6. Comparison of pair populations on stock-watering pond s in the Little Missouri and Heart River watersheds.

\begin{tabular}{|c|c|c|c|c|c|c|c|}
\hline \multirow[b]{2}{*}{ Species of duck } & \multicolumn{3}{|c|}{ Little Missouri River } & \multicolumn{3}{|c|}{ Heart River } & \multirow{2}{*}{$\begin{array}{l}\text { Ratio of } \\
\text { pairs/acre } \\
\text { between } \\
\text { watersheds }\end{array}$} \\
\hline & $\begin{array}{c}\text { Number } \\
\text { Pairs }\end{array}$ & $\begin{array}{l}\text { Pairs/ } \\
\text { Acre }\end{array}$ & $\begin{array}{c}\text { Percent } \\
\text { Pairs } \\
\end{array}$ & $\begin{array}{c}\text { Number } \\
\text { Pairs }\end{array}$ & $\begin{array}{l}\text { Pairs/ } \\
\text { Acre }\end{array}$ & $\begin{array}{c}\text { Percent } \\
\text { Pairs }\end{array}$ & \\
\hline Mallard & 123 & .88 & 68 & 85 & .89 & 36 & $1.0: 1$ \\
\hline Gadwall & 7 & .05 & 04 & 11 & .12 & 05 & $0.4: 1$ \\
\hline Pintail & 8 & .06 & 04 & 41 & .43 & 18 & $0.1: 1$ \\
\hline Green-winged teal & 13 & .09 & 07 & 6 & .06 & 03 & $1.5: 1$ \\
\hline Blue-winged teal & 9 & .06 & 05 & 38 & .40 & 16 & $0.2: 1$ \\
\hline American widgeon & 20 & .14 & 11 & 40 & .42 & 17 & $0.3: 1$ \\
\hline Shoveler & 2 & .01 & 01 & 12 & .13 & 05 & $0.1: 1$ \\
\hline Total or average & 182 & 1.29 & 100 & 233 & 2.45 & 100 & $0.5: 1$ \\
\hline
\end{tabular}

In Montana, Gjersing (1971) found that brood numbers per pond increased as the amount of pond area $2 \mathrm{ft}$ deep and less increased.

\section{Duck-Use and Pond Feature Relationships}

The $t$ values of the more important relationships between pair use and pond habitat factors are shown in Table 7. Pairs of mallards and of all species combined were positively related to pond age. The removal of topsoil and plants during construction possibly resulted in lower use of ponds less than 5 years old. As plants and nutrients gradually increased in the pond, use by pairs increased. In the eastern United States the reverse usually occurs, duck numbers decreasing as ponds increase in age (Benson and Foley, 1956; Kadlec, 1962). This results from a combination of factors, including less fertile water and soil, less seasonal drying, increased humic staining, and higher soluble iron concentrations (Cook, 1964).

As the distance from a pond to other water increased, use of the pond by pairs generally decreased. Mallards, which have large breeding territories (Dzubin, 1955), were an exception and uscd even the most isolated ponds in the study area. Most species, however, apparently were unable to utilize a pond providing mainly territorial space which was separated from water providing the other needs for pair support. In studies of small excavated ponds, Cooch (1950) and Hammond and Lacy (1960) found more pairs on those near marshes. Cooch concluded that pair use of dugouts was related to the density of natural wetlands in the vicinity.

It was difficult to determine the shoreline preferences of breeding pairs because of the combination of cover types encircling each pond. However, pairs seemed to prefer open shorelines, with American widgeon positively related to bare and grassy shorelines and all species combined significantly associated with grassy shorelines. Bue et al. (1952) noted that grassy shorelines had more mallard, pintail, and blue-winged teal pairs than did bare shores. On his study area, shorelines that were partly grass and partly bare had intermediate use by pairs.

Pair use by mallards, American widgeon, and all species combined was significantly less in silted ponds. A significant positive correlation between blue-winged teal and siltation resulted because one silted pond developed a new fertile substrata and received heavy use by bluewings. Heavy siltation covers vegetation, increases turbidity, and shortens the pond life.

The more important relationships between brood use and pond habitat features are shown in Table 8. As with pairs, brood use increased as pond age increased, but decreased notably as the distance between ponds increased. Newly built ponds in Montana also had less use by broods (Gjersing, 1971). Broods, unlike pairs, were not significantly influenced by siltation, but mallard broods were significantly less numerous on turbid ponds.

Pintail broods generally use vegetation for escape cover. They were positively related to ponds with emergent vegetation. Blue-winged teal and American widgeon broods usually move to open water for safety. Blue-winged teal were not significantly associated with ponds containing emergent vegetation, and American widgeon were negatively related to this feature.

Broods of most species were positively correlated with brushy shorelines. The optimum in brood cover for most species appeared to be flooded brush or emergent vegetation which allows a brood to remain on the water but with overhead protection. Berg (1956) found that while
Table 7. Computed $t$ values of multiple regression coefficients between pair use and certain pond characteristics. ${ }^{1}$

\begin{tabular}{|c|c|c|c|c|c|}
\hline \multirow[b]{2}{*}{$\begin{array}{c}\text { Pond } \\
\text { characteristics }\end{array}$} & \multicolumn{4}{|c|}{ Species of duck } & \multirow[b]{2}{*}{$\begin{array}{c}\text { All } \\
\text { species }\end{array}$} \\
\hline & Mallard & $\begin{array}{c}\text { American } \\
\text { widgeon }\end{array}$ & $\begin{array}{c}\text { Blue-winged } \\
\text { teal }\end{array}$ & Pintail & \\
\hline Age & $2.59 * *$ & 0.86 & 1.34 & 0.18 & $2.51 * *$ \\
\hline $\begin{array}{l}\text { Distance to } \\
\text { other water }\end{array}$ & 058 & & & & \\
\hline Bare shore & $\begin{array}{l}0.58 \\
0.87\end{array}$ & $1.84 *$ & $\begin{array}{l}-1.10 \\
-1.40\end{array}$ & 0.97 & $\begin{array}{l}-1.80 \\
1.31\end{array}$ \\
\hline Grassy shore & 1.48 & $2.19 * *$ & -1.23 & 1.21 & $1.75^{*}$ \\
\hline Silted bottom & $-1.81 *$ & $-2.32 * *$ & $1.83^{*}$ & -1.15 & $-1.66^{*}$ \\
\hline
\end{tabular}

Table 8. Computed $t$ values of multiple regression coefficients between brood use and certain pond characteristics. ${ }^{1}$

\begin{tabular}{|c|c|c|c|c|c|}
\hline \multirow[b]{2}{*}{$\begin{array}{c}\text { Pond } \\
\text { characteristics }\end{array}$} & \multicolumn{4}{|c|}{ Species of duck } & \multirow[b]{2}{*}{$\begin{array}{c}\text { All } \\
\text { species }\end{array}$} \\
\hline & Mallard & $\begin{array}{c}\text { American } \\
\text { widgeon }\end{array}$ & $\begin{array}{c}\text { Blue-winged } \\
\text { teal }\end{array}$ & Pintail & \\
\hline Age & $4.40^{* *}$ & $2.14 * *$ & 0.77 & $1.69 *$ & $4.73 * *$ \\
\hline \multicolumn{6}{|l|}{ Distance to } \\
\hline Turbidity & $-2.43^{* *}$ & -0.60 & 1.14 & 0.05 & -1.53 \\
\hline \multicolumn{6}{|l|}{ Emergent } \\
\hline vegetation & 0.85 & $-3.55 * *$ & 0.69 & $2.89 * *$ & 0.29 \\
\hline Brushy shore & $2.45^{* *}$ & $2.21^{* *}$ & 0.12 & 1.18 & $3.02 * *$ \\
\hline
\end{tabular}




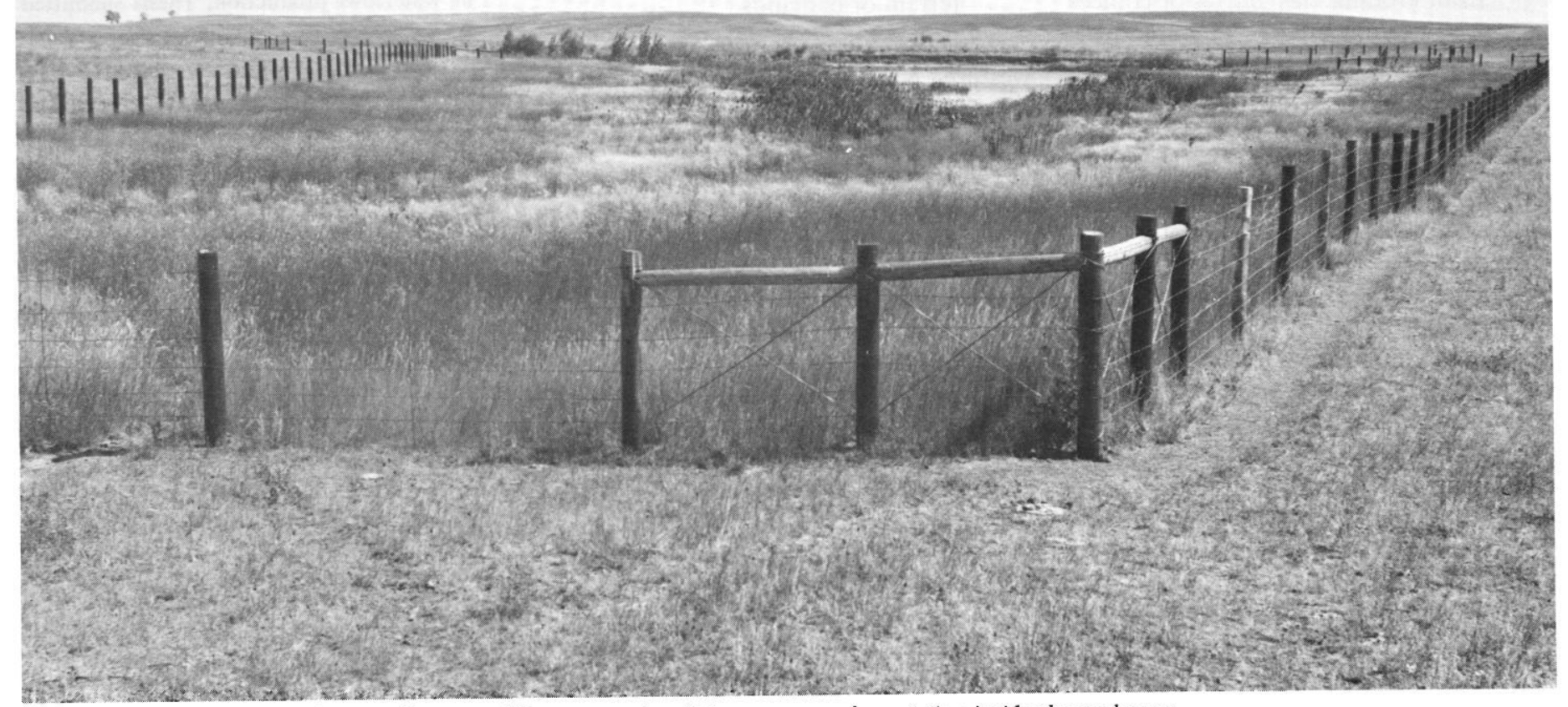

Fig. 2. Fenced stock pond showing the type of fence erected and the response of vegetation inside the exclosure.

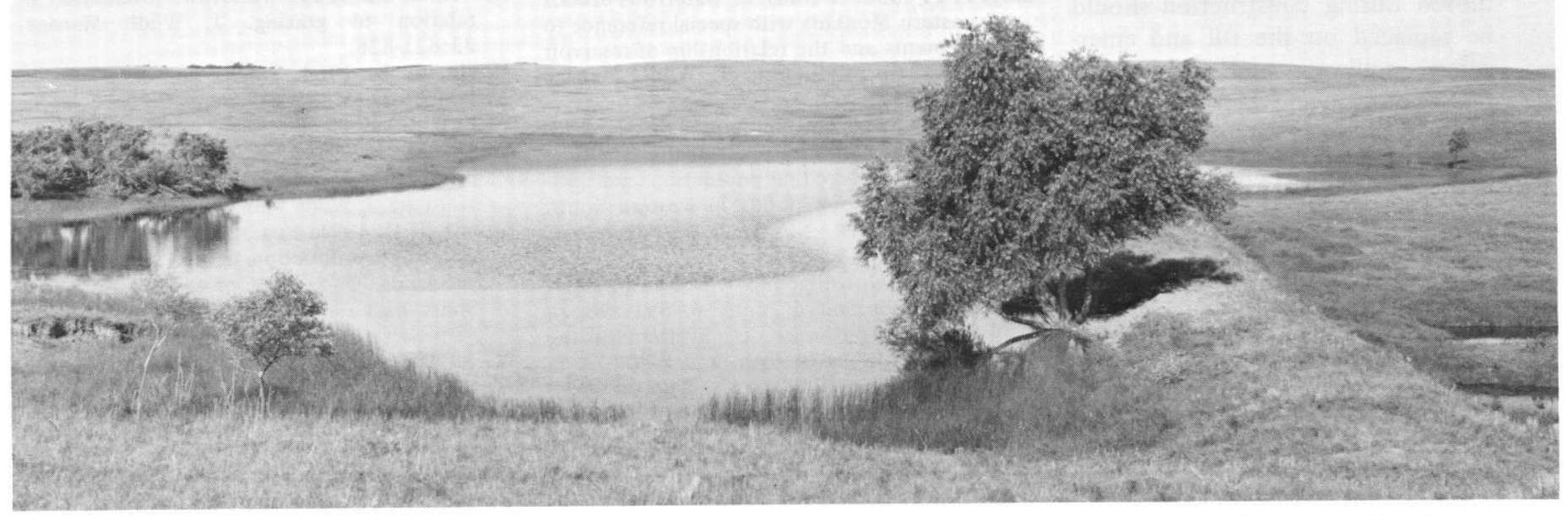

Fig. 3. This stock pond is attractive to waterfowl because it is situated on a moderately rolling site near other water, has a grassy shoreline, emergent vegetation, no sediment problem, and is an excellent size for this area of 4 surface acres.

pond size was more important to broods than plant cover, broods preferred ponds with emergent vegetation. Bue et al. (1952) noted that broods, as did pairs, preferred grassy shorelines rather than bare shorelines. In central Montana, Gjersing (1971) concluded that "brood numbers seemed to respond in a positive manner to increases in residual vegetation" on the shoreline.

\section{Management Suggestions}

On the basis of the findings of this and other studies, small reservoirs constructed for watering livestock can be made more beneficial to waterfowl (Fig. 3) if the following points are kept in mind:
1) Pond size is the most important feature affecting waterfowl use. In any given unit of rangeland, only a set number of ponds are constructed, so to be of the greatest value to waterfowl each pond should be designed to obtain maximum use by duck pairs and broods.

The smallest pond size recommended is 1.5 acres because it usually would not be reduced to less than 1.0 acre in summer, the minimum size suggested for brood support. The maximum pond size need be restricted only by the site available and economics; however, large ponds have fewer ducks per unit area, and more pair and brood use will occur on two ponds with the same total surface area as one large pond.

2) Of the three pond types examined, stock ponds are most important to breeding waterfowl because of their larger average size. Dugouts and diked dugouts are of little use to broods and have low unit-pond use by breeding pairs. If an excavated pond is the only alternative, dikeddugouts are more valuable to ducks than are dugouts.

3) Ponds should not be built on sites 
where large volumes of sediment from eroding clay buttes or coulees will wash into the impoundment. Thick deposits of sediment reduce food and cover plants, shorten the pond life, and reduce duck use.

4) Breeding pairs of most species prefer grassy rather than bare shorelines, and broods generally seek shorelines with clumps of brush or emergent vegetation. An important part of any plan to increase waterfowl productivity is the management of upland cover for nesting. Although nest-vegetation relationships were not a part of this study, other authors have noted that lightly used or unused upland vegetation containing dead litter from the previous year forms the best nesting cover for ducks (Moyle, 1964; Kirsch, 1969; Gjersing, 1971).

5) As much topsoil as possible should be allowed to remain in the impoundment site. Topsoil removed during construction should be replaced on the fill and emergency spillway and seeded to reduce erosion and dam loss.

6) Ponds, particularly smaller ones, should be constructed near other ponds or wetlands. The needs of breeding waterfowl are often obtained from several closely associated ponds. Isolated ponds lacking one important requirement may be unused.

7) Impoundments should be built in rolling terrain rather than rugged terrain or badlands.

Many of the new ponds being built in western North Dakota are dugouts or diked-dugouts of little value to waterfowl. If ponds are built on federal lands or with federal assistance, wildlife production can be benefited by constructing stock ponds that are 1.5 acres or larger. On private land the current federal costsharing rate for construction of stockwatering ponds is 60 to $70 \%$. To encourage the construction of ponds that have the greatest value to breeding waterfowl, the rate should be increased to $90 \%$ for dam-type ponds and 70\% for dikeddugouts. For federal lands, guidelines should be changed to encourage construction of types and sizes in the above management suggestions.

\section{Literature Cited}

Benson, D., and D. Foley. 1956. Waterfowl use of small, man-made wildlife marshes in New York State. New York Fish and Game J. 3:217-224.

Berg, P. F. 1956. A study of waterfowl broods in eastern Montana with special reference to movements and the relationship of reservoir fencing to production. J. Wildl. Manage. 20:253-262.

Bue, I. G., L. Blankenship, and W. H. Marshall. 1952. The relationship of grazing practices to waterfowl breeding populations and production on stock ponds in western South Dakota. Trans. N. Amer. Wildl. Conf. 17:396-414.

Bue, I. G., H. G. Uhlig, and J. D. Smith. 1964. Stock ponds and dugouts. p. 391-398. In Waterfowl Tomorrow. U. S. Dep. of the Interior, Bur. Sport Fish. and Wildl., J. P. Linduska (Editor). 770 p.

Cooch, G. 1950. The Prairie Farm Rehabilita- tion Act dugouts of Manitoba and their role in waterfowl production. Thesis submitted to Queen's Univ., Kingston, Ont., Canada. $140 \mathrm{p}$.

Cook, A. H. 1964. Better living for ducksthrough chemistry. p. 569-578. In Waterfowl Tomorrow. U. S. Dep. of the Interior, Bur. Sport Fish. and Wildl., J. P. Linduska (Editor). $770 \mathrm{p}$.

Dzubin, A. 1955. Some evidences of home range in waterfowl. Trans. N. Amer. Wildl. Conf. 20:278-298.

Evans, C. D., and K. E. Black. 1956. Duck production studies on the prairie potholes of South Dakota. U. S. Fish and Wildl. Serv. Spec. Sci. Rep. Wildl. No. 32.59 p.

Gjersing, F. M. 1971. A study of waterfowl production on two rest rotation grazing units in northcentral Montana. M. S. Thesis. Montana State Univ. Bozeman. 42 p.

Hammond, M. C., and C. H. Lacy. 1960. Ducks from artificial water areas. Conservation Volunteer. 23(135):21-26.

Jones, R. E. 1968. A board to measure cover used by prairie grouse. J. Wildl. Manage. 32:28-31.

Kadlec, J. A. 1962. Effects of a drawdown on a waterfowl impoundment. Ecology. 43:267-281.

Keith, L. B. 1961. A study of waterfowl ecology on small impoundments in southeastern Alberta. Wildl. Monogr. 6. 88 p.

Kirsch, L. M. 1969. Waterfowl production in relation to grazing. J. Wildl. Manage. 33:821-828.

Moyle, J. B. 1964. Ducks and land use in Minnesota. Minnesota Dept. Conserv. Tech. Bull. 8. 140 p.

Smith, R. H. 1953. A study of waterfowl production on artificial reservoirs in eastern Montana. J. Wildl. Manage. 17:276-291.

Stoudt, J. H. 1971. Ecological factors affecting waterfowl production in the Saskatchewan parklands. U. S. Dep. of the Interior, Bur. Sport Fish. and Wildl., Res. Pub. No. 99. $58 \mathrm{p}$.

U. S. Dep. of Commerce, Weather Bureau. 1970. Climatological data-North Dakota. Annu. Summary, Vol. 75. Asheville, N. C.

\section{Q3 \\ SCIENCE AND MAN in the americas}

mexico city•june 20-july 4, 1973

\section{AAAS/CONACYT}

For additional information see the February and April issues of Rangeman's News or write to Consejo Nacional de Ciencia y Tecnología, Av. Insurgentes Sur No. 1677. México, 20, D.F., México. 